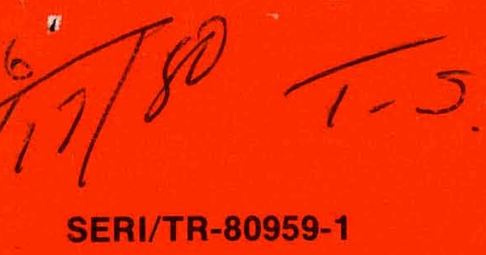

\title{
MASTER
}

\section{Standards for Photovoltaic Energy Conversion Systems}

\section{Final Report}

Harry A. Schafft

National Bureau of Standards Department of Commerce Washington, D.C.

Prepared Under Subcontract No. XD-8-0959-1 for the
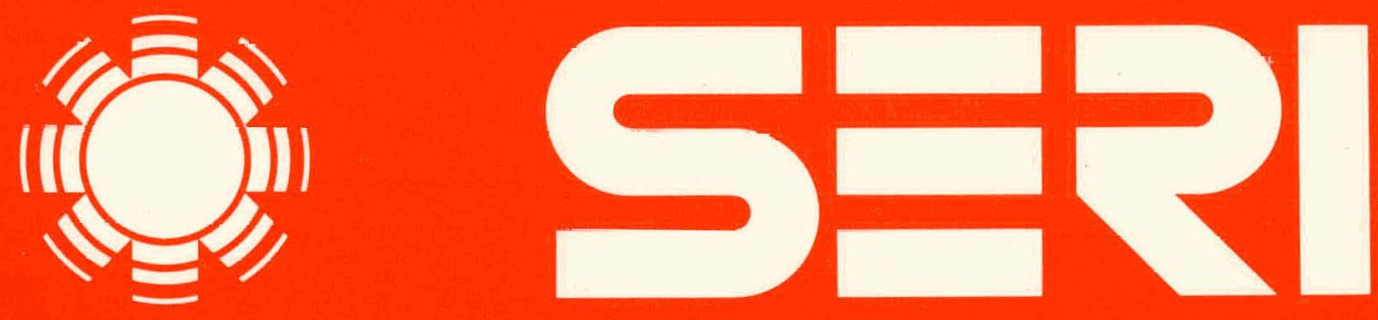

Solar Energy Research Institute A Division of Midwest Research Institute

1617 Cole Boulevard

Golden, Colorado 80401

Operated for the U.S. Department of Energy under Contract No. EG-77-C-01-4042 


\section{DISCLAIMER}

This report was prepared as an account of work sponsored by an agency of the United States Government. Neither the United States Government nor any agency Thereof, nor any of their employees, makes any warranty, express or implied, or assumes any legal liability or responsibility for the accuracy, completeness, or usefulness of any information, apparatus, product, or process disclosed, or represents that its use would not infringe privately owned rights. Reference herein to any specific commercial product, process, or service by trade name, trademark, manufacturer, or otherwise does not necessarily constitute or imply its endorsement, recommendation, or favoring by the United States Government or any agency thereof. The views and opinions of authors expressed herein do not necessarily state or reflect those of the United States Government or any agency thereof. 


\section{DISCLAIMER}

Portions of this document may be illegible in electronic image products. Images are produced from the best available original document. 
Printed in the United States of America Available from:

National Technical Information Service

U.S. Department of Commerce

5285 Port Royal Road

Springfield, VA 22161

Price:

Microfiche $\$ 3.00$

Printed Copy $\$ 4.00$

\section{NOTICE}

This report was prepared as an account of work sponsored by the United States Government. Neither the United States nor the United States Department of Energy, nor any of their employees, nor any of their contractors, subcontractors, or their employees, makes any warranty, express or implied, or assumes any legal liability or responsibility for the accuracy, completeness or usefulness of any information, apparatus, product or process disclosed, or represents that its use would not infringe privately owned rights. 
SERI /TR-80959-1

UC CATEGORY: UC -63

\section{MASTER}

STANDARDS FOR PHOTOVOLTAIC

ENERGY CONVERSION SYSTEMS

FINAL REPORT

HARRY A. SCHAFFT

APRIL 1980

NATIONAL BUREAU OF STANDARDS

DEPARTMENT OF COMMERCE

WASHINGTON, D.C.

PREPARED UNDER SUBCONTRACT

NO. XD-8-0959-1

FOR THE

Solar Energy Research Institute

A Division of Midwest Research institute

1617 Cole Boulevard

Golden, Colorado 80401

Prepared for the

U.S. Department of Energy

Contract No. EG-77-C-01-4042

SERI PROJECT MANAGER:

DISCLAIMER

GARY NUSS

This book was prepared as an account of work sponsored by an ageney of the United States Government.

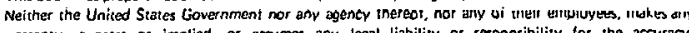
warranty. express or implied. Or assumes any legal liability of responsibility of the accuracy. completenes. 0 . 


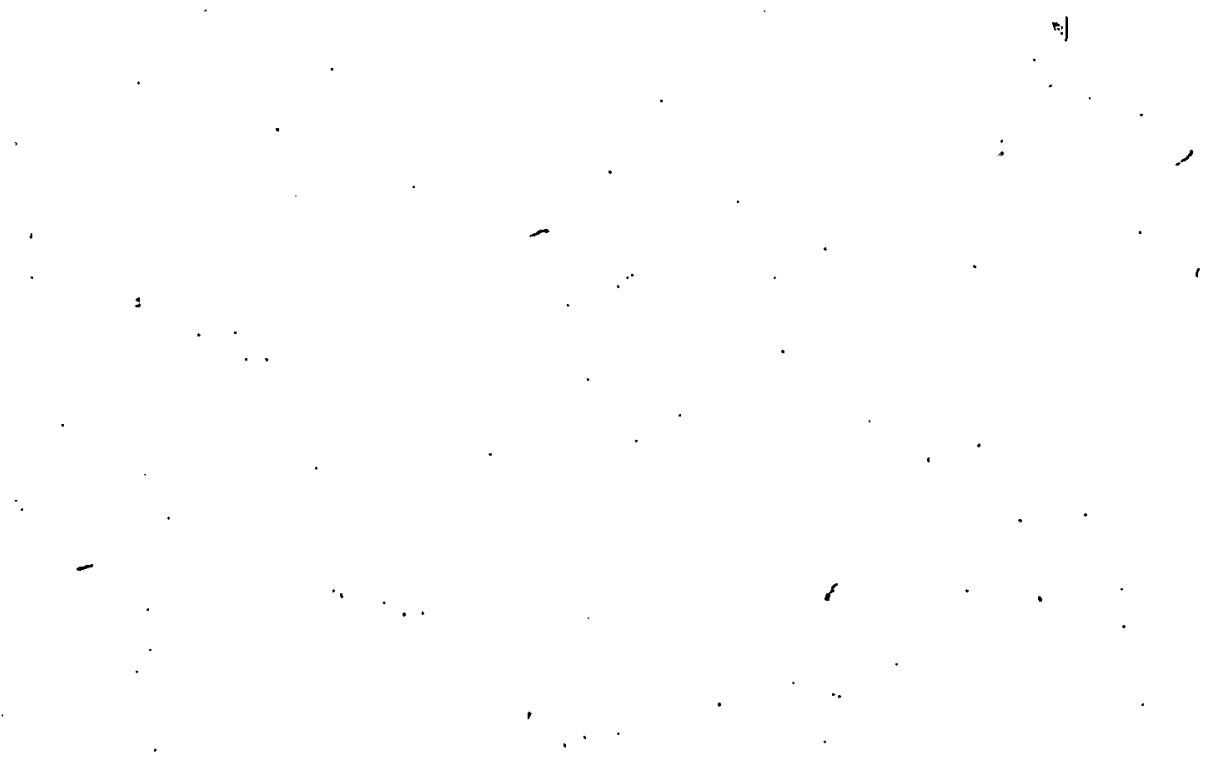

THIS PAGE

WAS INTENTIONALLY

$\therefore \mathbb{L E F} \mathbb{T}$ BLANK 


\section{FOREWORD}

This report is the result of a search for existing domestic standards and related documents for possible application in the development of a standards base for photovoltaic energy conversion systems.

The Department of Energy funded this work under contract number EG-77C-01-4042, through the Solar Energy Research Institute (SERI). The work was performed by the National Bureau of Standards. SERI is the project manager for the Photovoltaic Performance Criteria and Test Standards Project.

This study is intended to assist the working groups involved in developing performance criteria for photovoltaic systems and to identify methods to test system performance against these criteria.

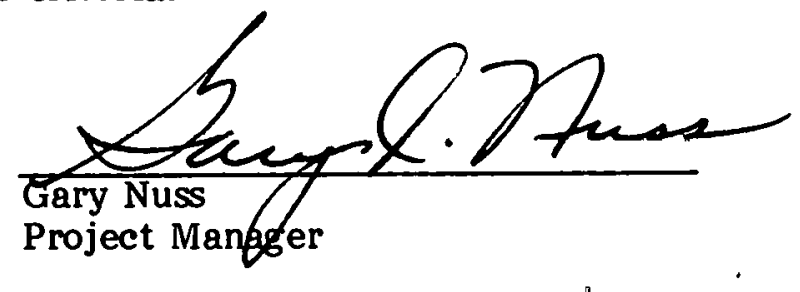


Standards for Photovoltaic

Energy Conversion Systems

by

\author{
Harry A. Schafft \\ Electron Devices Division \\ Center for Electronics and Electrical Engineering \\ National Bureau of Standards \\ Washington, D.C. 20234
}

\begin{abstract}
This report provides the results of a search for existing domestic standards and related documents for possible application in the development of a standards base for photovoltaic energy conversion systems. The search resulted in locating about 150 test methods, recommended practices, standards, solar-thermal performance criteria, and other standards-related documents. They are 1 isted by topic areas in the appendix. The 1 isting was prepared to assist those involved in developing performance criteria for photovoltaic systems and in identifying methods to test system performance against these criteria. It is clear from the results of the search that few standards are directly applicable to terrestrial solar photovoltaic systems and that much standards development is required to support the commercialization of such systems.
\end{abstract}

A search was conducted for existing domestic standards and related documents which might be applicable. for use in the development of a standards base for photovoltaic energy conversion systems. The search was part of an effort directed by the Comercial Readiness Branch of the Solar Energy Research Institute (SERI) to develop such a base. 1

Among the elements of the SERI effort is the preparation of an Interim Performance Criteria document. This document will provide the performance criteria for photovoltaic systems and their components, and specify the methods to test system performance against these criteria. The search was conducted to provide the groups preparing this document with a listing of existing standards and related documents of possible application to terrestrial photovoltaics.

The sources used for the search are listed in table 1. These sources include two solar hearing and cooling documents prepared by the National

${ }^{1}$ This work was performed under SERI purchase order XD-8-0959-1 and funded by the Department of Energy under contract number EG-77-C-01-4042 of the Division of Solar Technology. 
Bureau of Standards which taken together represent the primary source on which depend many other documents and $s$ andards in the solar thermal area. These documents ${ }^{2}$ provided a significant number of relevant items related to the following performance attributes: mechanical, structural, durability and reliability, and safety.

Of the catalogs of $s$ andards and related documents searched, the catalog of standards by the Institute of Electrical and Electronics Engineers (IEEE) provided the most entries. This catalog was a source for numerous documents of potential interest, especially for power conditioning and control, for cables, and for storage components of photovoltaic power conversion systems.

Another source used was An Index of U.S. Voluntary Engineering Standards, NBS Special Publication 329, together with its two supplements. While overlapping the scopes of many of the other sources, the Index with its permuted titleo facilitaled the search process and offered the opportunity of double checking the search of the other sources. The Department of Defense Index of Specifications and Standards was also searched for applicable military standards to supplement the standards-relaced materials from the voluntary standards arena.

The method of selecting standards and related materials involved an examination of the titles to make preliminary selections, followed by an examination of the scope, purpose, and other descriptive material, if necessary, to make the final selections. Emphasis in the selection was placed on including items relevant only to the following subsystem levels: solar cells (and hierarchical assemblies of cells), storage (batteries), power conditioning and control, and cables.

Approximately 150 titles of performance criteria, tests, standards, and reports of potential application to photovoltaic systems which were found in the search are 1 isted in Appendix A. References to these titles follow in brackets for each entry. Information about obtaining copies of these items may be obtained by using the addresses and telephone numbers listed with the sources in table 1. In all but a few cases, it will be obvious with which source listed in table 1 an entry is associated, that is, the NBS Interagency Reports (NBSIR), the catalogs of the five standards organizations, and the Department of Defense Index. In the few cases where this is not 80 , an address or other information is provided in the brackets for the antry.

To determine if IEEE standards projecto underway wight be of interest, a list of Standards Projects and Responsibilities (April 6, 1y78) was ob=

20ne of these, NBSIR 76-1187, which provides interim performance criteria for solar heating and cooling systems in comercial buildings, is based on an earlier document on performance criteria for such systems in residential buildings. This earlier document has recently been revised and it is now available as NBSIR 78-1562. 
tained from the IEEE Standards office and reviewed. The only project found to be of interest is one on Harmonics and Reactive Compensation of Static Converters of Electric Power. A preliminary report of the project committee ${ }^{3}$ has been presented publicly for comments. ${ }^{4}$ As a result of comments received, the committee is preparing a section on selfcommutating inverters and their use to reduce the effect of harmonics.

One important observation can be made now that the search for standards of possible applicability to photovoltaic systems and their components has been completed. The present standards base for solar photovoltaics is clearly inadequate and will require considerable effort to develop to a level required to support the desired commercialization of solar photovoltaic systems. Few, if any, of the standards listed appear to be transferable without significant modification. In many of the standards, only parts appear to be applicable to solar photovoltaics. Other standards, not directly applicable to solar photovoltaic systems, are included in the listing primarily to remind the task groups that will develop performance criteria of aspects of possible importance. Many standardo deal with generalized topics of safety, reliability, quality assurance, and durability and so represent a source from which to draw when considering performance criteria related to these aspects of solar photovoltaics.

The scope of this effort was limited to searching the standards literature. There is another source, however, that should contain documents useful for developing the desired standards base for photovoltic systems. This source is the government and published 1 iterature and other documents generated by members of the photovoltaic community. If they exist anywhere, the raw materials for the standards base will be found in this literature. For example, the effort by the SERI Advisory committee 5 in defining the hierarchical terms for solar-cell assemblies represents the best effort thus far in definitions. This compilation is an excellent candidate for consideration by a standards writing organization. The NASA document on Terrestrial Photovoltaic Measurement Procedures (ERDA/NASA/1022-77/16, NASA TM 73702, June 1977) is another example of a report which contains useful information. Portions of this document, as well as the aforementioned definitions, are already being considered by ASTM Committee E44 on Solar Energy Conversion as draft standards from which to develop consensus standards for photovoltics.

3Standards project contact: R. P. Stratford, General Electric Co., Schenectady, NY. Tel: (518) 385-2299.

${ }^{4}$ Guide for Harmonic Control and Reactive Compensation of Static Power Converters, Report of Subcommittee on Harmonic Control and Reactive Compensation of Static Power Converter Committee of IEEE - IAS, Record, International Semiconductor Power Converter Conference, Orlando, Florida, March 1977, pp. 172-176.

${ }^{5}$ Organized by the Commercial Readiness Branch of SERI. 
Table 1. Sources Used in Search of Standards Applicable to Photovoltaic Energy Conversion Systems.

\section{Source}

Interim Performance Criteria for Solar Heating and Cooling Systems in Commercial Buildings, NBSIR 76-1187 (Available from the National Technical Information Service, U.S. Department of Commerce, Springfield, VA 22161 , using the order number PB262114. Tel: (703) 321-8543]

Provisional Flat Plate Solar Collector Testing Procedures, NBSIR 77-1305 [Available from the National Technical Inforwatiun Service, U.S. Department of commerce, Springficld, VA 22161, using the order number PB272500. Tel: (703) 321-8543]

Institute of Filertical and Electronies Enginets (IEEE) Standards Catalog (Available from the IEEE Headquarters, 345 East 47 th St., New York, NY 10017. Tel: (212) 644-7960].

National Electrical Manufacturers Association (NEMA) Standards Publications Catalog [Available from NEMA, 2101 L Street, N.W., Washington, DC 20037. Tel: (202) 457-8473]

Index of Electronic Industries Association (EIA) and Joint Electron Device Engineering Councils (JEDEC) Standards and Engineering Publications (Available from EIA, 20.01 Eye St., N.W., Washington, DC 20006. Tel: (202) 457-1900]

Catalog of Standards for Safety of the Underwriters Laboratories [Available from Underwriters Laboratories, Inc., 207 East Ohio St., Chicago, IL 60611. Tel: (312) 642-6969]

An Index of U.S. Voluntary Engineering Standards, NBS Special Publication 329 [Available from the National Technical Information Service, U.S. Departinent of Commerce, Springfield, VA 22161, using the order number COM71-50172. Tel: (703) 557-4780]

$a_{\text {Latest publication date of standards referenced. }}$
Publication Date

November 1976

September 1977

March 1978

March 1978

January 1978

January 1978

December 31, $1969^{a}$ 
An Index of U.S. Voluntary Engineering Standards, NBS December 31, $1969^{a}$ Special Publication 329, Supplement 1 [Available from the National Technical Information Service, U.S. Department of Commerce, Springfield, VA 22161, using the order number COM73-50679. Te1: (703) $557-4780]$

An Index of U.S. Voluntary Engineering Standards, NBS July 1, $1974^{a}$ Special Publication 329, Supplement 2 [Available from the Superintendent of Documents, U.S. Government Printing Office, Washingtion, DC 20402, using stock number 003-003-01362-5. Tel: (202) 783-3238]

Department of Defense Index of Specifications and Standards [Available from the Superintendent of Documents, U.S. Government Printing office, Washington, DC 20402, using stock number 003-00781001-4. Tel: (202) $783-3238]$

Catalog of American National Standards [Available August 1978

May 1, 1978 from the American Standards Institute, 1430 Broadway, New York, NY 10018. Te1: (212) 354-3300]

${ }^{a}$ Latest publication date of standards referenced. 


\section{Appendix A}

List of Test Methods, Recommended Practices, Standards, Related Standard Materials, Solar-Thermal Performance Criteria, and Other Materials of Potential Application to Photovoltaic Power Systems:

\section{CONTENTS}

Topic Areas

Page

BATTERIES

DURABILITY AND RELIABILITY
A. Effects of External Environwent:
B. Effects of nperating Extramca nf Temperitury and Pressile 8
C. Chemical Compatibility of Components
D. Reporting
E. Promotion and Evaluation of Durability and Reliability

MECHANICAL ATTRIBUTES
A. Heat Transfer Fluid System Design Conditions
R. Mechanical stresses
C. Orientation Adjustment

POWER SYSTEMS
A. Distribution
B. Protection
C. Control
D. Switches
E. Insulation
F. Cables
G. Crounding
H. Temperature Measurement. $,{ }^{2},{ }^{\prime} 12$
I. Definitions/Nomenclature 12
I. Electromagnctie Interfeience 12
K. Enclosures
L. Electrical Measurements

SAFETY

A. Electrical Safety 13

B. Fail-Safe Control 13

C. Fire Safety 13

D. Toxis and Flammable Fluid̦s 13

E. Safety Under Emergency Conditions 14

F. Excessive Surface Temperature 14

G. Safety and Health $\ldots 14$

H. General 14

$\begin{array}{ll}\text { SOLAR CELLS } & 14\end{array}$

$\begin{array}{lll}\text { STRUCTURAL ATTRIBUTES } & 14\end{array}$ 


\section{BATTERIES}

1. Recommended Practice for Maintenance, Testing, and Replacement of Large Lead Storage Batteries for Generating Stations and Substations [IEEE Standard 450-1975].

2. Standard for Electrical Safety Practices in Electrolytic Cell Line Working Zones [IEEE Standard 463-1977].

3. Recommended Practice for Installation Design and Installation of Large Lead Storage Batteries for Generating Stations and Substations. [IEEE Standard 484-1975; ANSI N41.24-1976].

4. Recommended Practice for Sizing Large Lead Storage Batteries for Generating Stations and Substations [IEEE Standard 485-1978].

5. Definitions for Lead-Acid Industrial Storage Batteries [NEMA Standard Publication [BI-1971(R1976)].

6. Capacity Determination of Lead-Acid Industrial storage Batteries for Motive Power Services [NEMA Standard Publication IB2-1974].

7. Cycle Life Testing of Lead-Acid Industrial Storage Batteries for Motive Power Service [NEMA Standard Publication IB3-1978].

8. National Electrical Safety Code, 1977 Edition [ANSI C2-1977].

9. Dictionary of Electrical and Electronics Terms [IEEE Standard 100-1977].

\section{DURABILITY AND RELIABILITY}

A. Effects of External Environment

Al Solar Degradation [Section 5.1.1; NBSIR 76-1187].

Ala Aging Procedure Using Artificial Light [Procedure 1, page 53; NBSIR 76-1187].

Alb Aging Procedure Using Concentrated Solar Radiation [Procedure 2, page 52; NBSIR 76-1187].

Alc Aging Procedure Using Unconcentrated Solar Radiation [Procedure 3, page 52; NBSIR 76-1187].

A2 Moisture [Section 5.1.2; NBSIR 76-1187].

A3 Soil-Related Degradation [Section 5.1.3; NBSIR 76-1187].

A3a Soil-Related Degradation Test Methodology [Section 04, page 59; NBSIR 76-1187].

A4 Airborne Pollutants [Section 5.1.4; NBSIR 76-1187].

A4a Resistance to Ozone Test Methodology [Section 05, page 59; NBSIR 76-1187].

A4b Resistance to Salt Spray Test Methodology [Section 05, page 60; NBSIR 76-1187].

A4c Resistance to $\mathrm{SO}_{2}, \mathrm{NO}_{x}$, and $\mathrm{HCl}$ Test Methodology 
[Section 05, page 60; NBSIR 76-1187].

A5 Dirt Retention on Cover Plate Surface [Section 5.1.5; NBSIR 76-1187].

A6 Abrasive Wear [Sections 5.1.6; NBSIR 76-1187].

A7 Fluttering by Wind [Section 5.1.7; NBSIR 76-1187].

A8 Military Standard, Environmental Test Methods [MIL-STD-810C].

A9 Military Standard, Moisture Resistance Test Cycle for Ground Signal and Electronic Test Equipment [MIL-STD-170].

Alo Standard Method of Test for Effect of Moisture and Temperature on Adhesive Bonds [ASTM D 1151-72].

All Standard Practice for Atmospheric Environmental Exposure Testing of Nonmetallic Materials [ANSI/ASTM G 7-77a]:

A12 Standard Recommended Practice for Outdoor Weathering of Plastics [ASTM D 1435-75].

A13 Standard Test Method for Resistance of Transparent plastics to Surface Abrasion [ASTM D 1044-76].

Al4 Standard Recommended Practice for Determining Hydrolytic Stability of Plastic Encapsulants for Electronic Devices [ASTM F 74-73].

Als Standard Method of Salt Spray (Fog) Testing [ASTM B 117-73].

Al6 Military Standardization Handbook, Corrosion and Corrosion Protection of Metals [MIL-HDBK-721 (MR)].

Al7 Standard Definitions of Terms Relating to Corrosion and Corrosion Testing [ASTM G 15-76].

B. Effects of Operating Extremes of Temperature and Pressure

B1 Thermal Cycling Stresses [Section 5.2.3; NBSIR 76-1187].

Bla Thermal Cycling Stress Test Methodology [Section 08, page 61; NBSIR 76-1187].

B2 Deterioration of Fluids Test Methodology [Section 5.2.2; NBSIR 76-1187].

B2a Deterioration of Fluids Test Methodology [Section 07, page 60; NBSIR 76=1187].

B3 Fluid Leakage [Section 5.2.4; NBSIR 76-1187].

BJa Fluid Leakaye Iest Mechodology [Section 09, page 61; NBSIR 76-1187].

C. Chemical Compatibility of Components

C1 Deterforation of Materials in Contact with Fluids [Section 5.3.1; NBSIR 76-1187].

Cla Deterioration of Materials Test Methodology [Section 10, page 61; NBSIR 76-1187].

C2 Materials Corrosion [Section 5.3.2; NBSIR 76-1187].

C2a Materials Corrosion Test Methodology [Section 11, page 62; NBSIR 76-1187].

C3 Compatibility of Dissimilar Materials [Section 5.3.3; NBSIR 76-1187].

C3a Compatibility of Dissimilar Materials Test Methodology [Section 12, page 62; NBSIR 76-1187]. 
C4 Effects of Decomposition Products [Section 5.3.5; NBSIR 76-1187].

C4a Effects of Decomposition Products Test Methodology

[Section 14, page 63; NBSIR 76-1187].

C5 Standard Methods of Test for Corrosive and Adhesive Effects of Gasket Materials on Metal Surfaces [ASTM F 64-69; (reapproved 1975); ANSI 2195.1-1970].

D. Reporting

D1 A General Guide for Technical Reporting of Electronic Systems Reliability Measurement [EIA Reliability Bulletin No. 1, December 1956].

D2 Reliability Quantification [EIA Reliability Bulletin No: 4, May 1969].

E. Promotion and Evaluation of Durability and Reliability

El Military Standard, Reliability Prediction [MIL-STD-756A].

E2 Military Standard, Reliability Evaluation from Demonstration Data [MIL-STD-757].

E3 Military Standard, Reliability Tests: Exponential Distribution [MIL-STD-7818].

E4 Military Standard, Reliability Program for Systems and Equipment Development and Production [MIL-STD-785A].

E5 Military Handbook, Sampling Procedures and Tables for Life and Reliability Testing (Based on Exponential Distribution) [Quality Control and Reliability Handbook (Interim) $\mathrm{H}-108$ ].

E6 Military Standard, Sampling Procedures and Tables for Inspection by Variables for Percent Defective [MIL-STD-414].

E7 Military Standard, Failure Rate Sampling Plans and Procedures [MIL-STD-690B].

E8 Military Handbook, Statistical Procedures for Determining Validity of Suppliers' Attributes Inspection [Quality Control and Rcliability Handhook (Interim) H-109).

E9 Recommended Practice for Acceptance of Evidence Based on the Results of Probability Sampling [ASTM E 141-69].

E10 Military Standard, Quality Assurance Terms and Definitions [MIL-STD-109B].

\section{MECHANICAL ATTRIBUTES}

A. Heat Transfer Fluid System Design Conditions

A1 Noise or Erosion-Corrosion [Section 2.1.2; NBSIR 76-1187].

A2 Fluid Flow [Section 2.1.4; NBSIR 76-1187].

A3 Entrapped Air [Section 2.1.5; NBSIR 76-1187].

A4 Thermal Expansion [Section 2.1.6; NBSIR 76-1187].

A5 Pressure Drops [Section 2.1.7; NBSIR 76-1187].

A6 Fluid Quality [Section 2.5.1; NBSIR 76-1187].

A7 Fluid Treatment [Section 2.5.2; NBSIR 76-1187]. 
A8 Freezing Protection [Section 2.5.4; NBSIR 76-1187].

B. Mechanical Stresses

B1 Vibration Stress [Section 2.2.1; NBSIR 76-1187].

B2 Vibration from Moving Parts [Section 2.2.2; NBSIR 76-1187].

B3 Thermal Changes [Section 2.2.5; NBSIR 76-1187].

B4 Standard Definitions of Terms Relating to Methods of Mechanical Testing [ANSI/ASTM E 6-76].

c. Orientation Adjustment

CI. Orientation and Tilt [Section 2.4.1; NBSIR 76-1187].

C2 Mutual Shadowing [Section 2.4.2; NBSIR 76-1187].

POWER SYSTEMS

A. Distribution

Al Recommended Practice for Electric Power Distribution for Industrial Plants [IEEE Standard 141-1976].

B. Protection

B1 Recommended Practice for Protection and Coordination of Industrial and Commercial Power Systems [IEEE Standard 242-1975; the IEEE Buff Book].

C. Control

C1 Test Code for Industrial Control (600 Volts or Less) (IEEE Standard 74-1958].

C2 Industrial Controls and Systems (NEMA Standardo Document ICS-1970 (R1973)].

C. Gulde for the Installation of Electrical Equipment to Minimize Electrical Noise Inputs to Controllers from External Sources [IEEE Standard 518-1977].

C4 American National Standard for Industrial Control Apparatus General [ANSI C19.3-1973].

D. Switches

D1 Standard for Relays and Relay Systems Associated with Electric Power Apparatus [IEEE Standard 313-1971; ANSI C37.90-1971].

D2 Defintelons and Requirements for High-Voltage Air Switches, Insulators, and Bus Supports [IEEE Standard 324-1971; ANSI C37. 30-1971].

D3 Definitions for Power Switchgear [ANSI C37.100-1972].

D4 Standard for Switchgear Assemblies Including Metal-Enclosed Bus [IEEE Standard 27-1974; ANSI C37.20-1969, C37.20a-1970, C37.20b-1972, C37.20-1974]. 
D5 Guide for Surge Withstand Capability (SWC) Tests [IEEE Standard 472-1974; ANSI C37.90a-1974 (Supplement to IEEE Standard 313-1971, ANSI C37.90-1971)].

D6 Standard Guide for Evaluating the Effect of Solar Radiation on Outdoor Metal-Clad Switchgear [IEEE Standard 144-1971].

E. Insulation

El General Principles for Temperature Limits in the Rating of Electric Equipment [IEEE Standard 1-1969].

E2 Guide for the Preparation of Test Procedures for the Thermal Evaluation of Insulation Systems for Electric Equipment [IEEE Standard 99-1970].

E3 Guide for the Statistical. Analysis of Thermal Life Test Data [IEEE Standard 101-1972].

E4 Standard Definitions of Terms Relating to Electrical Insulation [ANSI/ASTM D 1711-75].

F. Cables

F1 Standard Test Procedures and Requirements for High-Voltage Alternating-Current Cable Terminations [IEEE Standard 48-1975].

F2 Test Procedure for Impulse Voltage Tests on Insulated Conductors [IEEE Standard 82-1963].

F3 Standard for Separable Insulated Connectors for Power Distribution Systems Above $600 \mathrm{~V}$ [ANSI/IEEE Standard 386-1977].

F4 Standard for Power Cable Joints [IEEE Standard 404-1977].

F5 Guide for the Design and Installation of Cable Systems in Power Generating Stations [IEEE Standard 422-1977].

F6 Guide for Testing and Inspection of Cable or Harness Assemblies [EIA Reliability Bulletin No. 6, April 1970].

F7 Military Standard, Test Methods for Electrical Connectors [MIL-STD-1344A].

F8 Federal Test Method Standard, Cable and Wire, Insulated; Methods of Testing [Fed. Test Method Std. 228; Source: DoD Index].

G. Grounding

G1 Recommended Practice for Grounding of Industrial and Commercial Power Systems [IEEE Standard 142-1972; the IEEE Green Book].

G2 Guide for Safety in Alternating-Current Substation Grounding [IEEE Standard 80-1976].

G3 Military Standard, Grounding, Bonding and Shielding Design Practices [MIL-STD-1857].

G4 Loss Prevention Data, Protective Grounding of Electrical Circuits and Equipment [Factory Mutual System 5-10, 14-10; Factory Mutual System, 1151 Boston-Providence Turnpike, Norwood, MA 02062. Tel: (617) 762-43001. 
H. Temperature Measurement

H1 Recommended Practice for General Principles of Temperature Measurement as Applied to Electrical Apparatus [IEEE Standard 119-1974].

I. Definitions/Nomenclature

I1 Definitions for Power Switchgear [ANSI C37.100-1972 (Revision of C37.100-1966)].

I 2 Definitions and Requirements for High-Voltage Air Switches, Insulators, and Bus Supports [IEEE Standard 324-1971; ANSI C37.30-1971].

I3 Nomenclature for Generating Station Electric Power Systems [IEEE Standard 505-1977].

I4 Dictionary of Electrical and Electronics Terms [IEEE Standard 100-1977].

I5 Military Standard, Definitions and System of Units, Electromagnetic Interference and Electromagnetic Compatibility Technology [MIL-STD-463A].

I6 Guiding Principles for the Selection of Reference Values for Electrical Standards [IEEE Standard 3-1962].

I7 American National Standard, Voltage Ratings for Electrical Power Systems and Equipment (60 Hz) [ANSI C84.1-1977].

I8 Military Standard, Electric Voltages, Alternating and Direct Current [MIL-STD-255A].

J. Electromagnetic Interference

J1 Military Standard, Electromagnetic Interference Characteristics, Requirements for Equipment [MIL-STD-461A].

J2 Military Standard, Electromagnetic Interference Characteris= tics, Measurement of [MIL-STD-462],

J3 Military Standard, Electromagnetic Interference, Test Requirements and Test Methods [MIL-STD-826A].

J4 Military Standard, Electromagnetic Compatibility, Requirements for Space Systems [MIL-STD-1541].

J5 Military Standard, Electromagnetic Compatibility (EMC) and Grounding Requirements for Space System Facilities [MIL-STD-1542].

J6 Military Standard, Definitions and System of Units, Electromagnetic Interference Technology [MIL-STD-463].

K. Enclosures

Kl American National Standard for Industrial Control Apparatus Enclosures [ANSI C19.4-1973].

K2 Military Standard, Definitions of and Basic Requirements for Enclosures for Electric and Electronic Equipmenc [MIL-STD108E]. 
L. Electrical Measurements

L1 Master Test Code for Electrical Measurements in Power Circuits [IEEE Standard 120-1955 (Reaffirmed 1972)].

L2 Military Standard, Test Provisions for Electronic Systems and Associated Equipment, Design Criteria for [MIL-STD-415D].

\section{SAFETY}

A. Electrical Safety

Al Electrical codes and Standards [Section 4.1.2; NBSIR 76-1187].

A2 National Electrical Safety Code, 1977 Edition [ANSI C2-1977].

A3 Recommended Practice for Electric Power Distribution for Industrial Plants [IEEE Standard 141-1976; the IEEE Red Book].

A4 Industrial Controls and Systems [NEMA Standards Document ICS-1970 (R 1975)].

A5 Guide for Safety in Alternating-Current Substation Grounding [IEEE Standard 80-1976].

A6 Electrical Safety Practices in Electrolytic Cell Line Working Zones [IEEE Standard 463-1977].

A7 Recommended Practice for Installation Design and Installation of Large Lead Storage Batteries for Generating Stations and Substations [IEEE Standard 484-1975; ANSI N41.24-1976].

A8 Standard for Safety for Access Control Systems Units [UL-294].

A9 American National Standard, Safety Requirements for Electrical and Electronic Measuring and Controlling Instrumentation [ANSI C39.5-1974].

B. Fail-Safe Control

B1 System Failure Prevention [Section 4.2.1; NBSIR 76-1187].

c. Fire Safety

C1 Fire Codes and Standards [Section 4.3.1; NBSIR 76-1187].

C2 Protection Against Auto-Ignition of Combustibles [Section 4.3.4; NBSIR 76-1187].

C3 Ignitability and Flammability Tests [EIA Recomended Standard RS-325A, March 1976].

D. Toxic and Flamable Fluids

D1 Fluids Requiring Special Handling [Section 4.4.1; NBSIK 76-1187].

D2 Liquid Flash Point [Section 4.4.2; NBSIR 76-1187].

D3 Detection of Toxic and Combustible Fluids [Section 4.4.3; NBSIR 76-1187].

D4 Provision of Catch Basins [Section 4.4.4; NBSIR 76-1187]. 
E. Safety Under Emergency Conditions

E1 Emergency Egress and Access [Section 4.5.1; NBSIR 76-1187].

E2 Identification and Location of Controls [Section 4.5.2; NBSIR 76-1187].

F. Excessive Surface Temperature

F1 Protection from Heated Components [Section 4.7.1; NBSIR 76-1187].

G. Safety and Health

G1 Safety and Health Standards [Section 4.1.3; NBSIR 7.6-1187].

H. General

H1 EIA System Safety Bibliography [EIA Safety Engineering Bulletin No. 2, August 1970].

H2 System Safety Analytical Techniques [EIA Safety Engineering Bulletin No. 3, May 1971].

H3 Design Specification Safety Digest Military Specifications and Standards [EIA Bafety Euyineering Bullecín No. 4, February 1972 ].

H4 American National Safety Color Code for Marking Physical Hazards [ANSI 253.1-1971].

\section{SOLAR CELLS}

1. Definitions of Terms for Solar Cells [IEEE Standard 307-1969].

2. Performance Test Procedure for Solar Cells and Calibration Procedure for Solar Cell Standarda for Space Vehicle Service [EIA Standard RS365, November 19691.

3. Standard Test Methods for Solar Energy Transmittance and Reflectance (Terrestrial) of Sheet Materials [ASTM E 424-71].

4. Dictionary of Electrical and Electronics Terms [IEEE Standard 100-1977].

5. Standard Recommended Practice for Operating Light-Exposure Apparatus (Xenon-Arc Type) With and without Water for Exposure of Nonmetallic Materials [ANSI/ASTM G 26-77].

6. Standard Recommended Practice for Operating Xenon-Arc Type Apparatus for Light Exposure of Nonmetallic Materials [ASM G 27-70].

7. Standard Recommended Practice for Xenon Arc-Type (Water-Cooled) Iight- and Water-Exposure Apparatus for Exposure of Plastics [ANSI/ASTM D 2565-76].

\section{STRUCTURAL ATTRIBUTES}

1. Load and Resiatance of Conventional Elements [Section 3.1.1; NBSIR 76-1187].

2. Building Code Requirements for Minimum Design Loads in Buildings and 
Other Structures [ANSI A58.1, 1972].

3. Resistance to Maximum Load of Nonconventional Elements [Section 3.1.2; NBSIR 76-1187].

4. Resistance to Cycle Loads of Nonconventional Elements [Section 3.1.3; NBSIR 76-1187].

5. Hail Damage [Section 3.1.5; NBSIR 76-1187].

6. Hail Load Test [Page 34; NBSIR 77-1305].

7. Resistance to Load Induced Damage [Section 3.2.1; NBSIR 76-1187].

8. Deflection Limitations of Nonconventional Elements [Section 3.2.2; NBSIR 76-1187].

9. Positive Live Loads [Page 22; NBSIR 77-1305].

10. Negative Live Loads [Page 25; NBSIR 77-1305].

11. Longitudinal Loads [Page 30; NBSIR 77-1305].

12. Static Pressure Leakage Test [Page 37; NBSIR 77-1305].

13. Thermal Shock Water Spray Test [Page 15; NBSIR 77-1305].

14. Thermal Cycling [Page 20; NBSIR 77-1305].

15. Rain Test [Page 17; NBSIR 77-1305].

16. Fire Test [Page 41; NBSIR 77-1305]. 


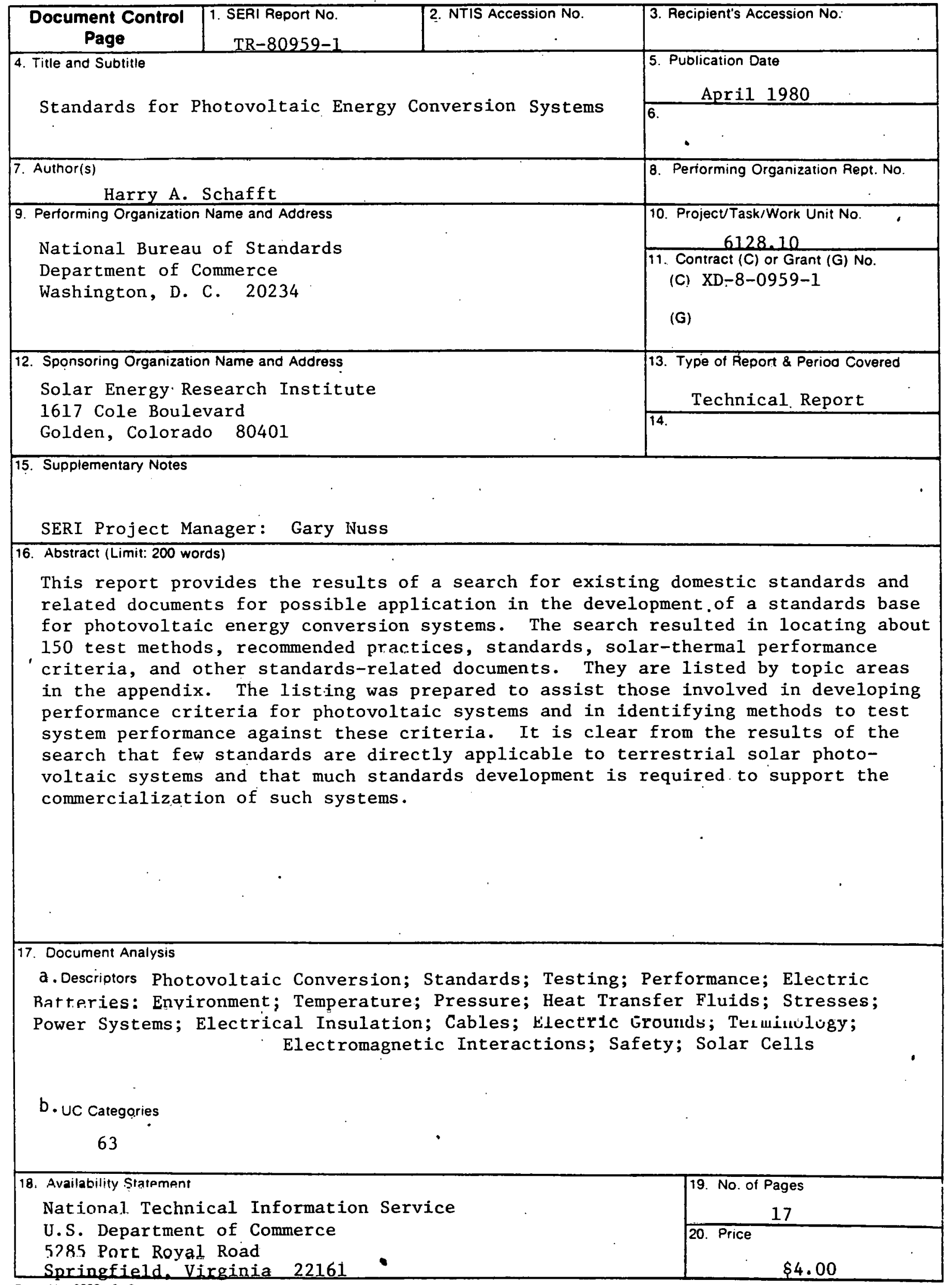

